\title{
Zinc Finger Protein Helios
}

National Cancer Institute

\section{Source}

National Cancer Institute. Zinc Finger Protein Helios. NCI Thesaurus. Code C80028.

Zinc finger protein Helios (526 aa, $\sim 60 \mathrm{kDa}$ ) is encoded by the human IKZF2 gene. This protein is involved in both lymphocyte development and transcription. 